\title{
Gypsum decay simulation: Risco de las Cuevas case study, Madrid, Spain
}

\author{
David Martín Freire-Lista ${ }^{1,2}$, Vladimir Greif ${ }^{3}$, Mónica Álvarez de Buergo ${ }^{1}$, \\ Rafael Fort ${ }^{1,2}$. \\ ${ }^{1}$ Instituto de Geociencias (CSIC, UCM) - Spanish Research Council-Complutense University \\ of Madrid, Spain. \\ ${ }^{2}$ CEI Campus Moncloa, UCM-UPM and CSIC, Madrid, Spain. \\ ${ }^{3}$ Department of Engineering Geology, Faculty of Natural Sciences, Comenius University in \\ Bratislava, Mlynska Dolina G, Bratislava, Slovakia.
}

Since troglodyte population has excavated their dwellings in the gypsum escarpment of the Risco de las Cuevas of Perales de Tajuña (Spain), atmospheric processes have preferentially sculptured the rockwall. This weathering has a negative effect on the future of the monument, and to preserve it, it is important to investigate how the different content of clay in the gypsum that constitute the escarpment, respond to the weathering.

Three types of gypsum, with different amounts of clay, material that constitute El Risco de las Cuevas, were subjected to accelerated ageing tests in laboratory (freezing/thawing and wetting/drying).

In addition to laboratory observations, results from field observations and digital photogrammetry were obtained, serving to draw the geometry of the escarpment, comparing with old photographs, taken by neighbors of the village of Perales de Tajuña, in which images of the detached tape bock of gypsum can be seen, their dimensions and volume. All artificial accelerated ageing tests have leaded to gypsum caused decay, being the most aggressive the resistance to freezing in the gypsum specimens with the highest clay content.

Keywords: Gypsum, grottoes, ageing test, weathering, photogrammetry

\section{Introduction}

El Risco de las Cuevas is a gypsum escarpment, Fig1) in which grottoes have been excavated from late Neolithic to recent times [1]. This rockwall is located in the province of Madrid, in Perales de Tajuña, $40 \mathrm{Km}$ Southeast of Madrid city, $40^{\circ} 14^{\prime} 0.3^{\prime \prime} \mathrm{N} 3^{\circ} 19^{\prime} 55^{\prime \prime} \mathrm{O}$. The environmental conditions and microclimate [2] produce several weathering processes [3] that might endanger this piece of cultural heritage. 
This area was declared Historical-Artistic Monument in 1931. In 1998 it was listed as BIC (cultural asset of interest) by the regional government of Madrid with Monument category under the "historical, architectonic, archaeological, artistic, ethnographic and scientific [4], for being a product of human activity of outstanding cultural interest.

The action of atmospheric agents [5], with a Mediterranean continental climate, since the Neolithic caused weathering of the whole escarpment, endangering the integrity of the caves, jeopardizing the whole monument [6].

This research is focused on the evaluation of decay processes of the gypsum beds that constitute the natural and cultural heritage property of El Risco de las Cuevas. The aim is to establish the causes of its decay and to propose preservation measures for this area, studying the evident interactions between Man, natural slope evolution and heritage. Aiming at preventive conservation rather than an intervention.

\section{Geological setting}

The escarpment where the caves were excavated belongs to the Lower Miocene unit of the Madrid Basin [7]. It is overlaid by the Lower-Mid Miocene Intermediate Unit, which is formed by carbonates (limestones and dolostones) along with other materials like clays, gypsum and flint. This forms the top of the sequence outcropping in this area. There are debris cones formed at the bottom of the rockwall made up of mixture of debris from the Lower, Medium and Upper Units. The escarpment, 70 meters high and 500 meters wide, was created by reactivation of Variscan faults during the Alpine orogeny [8], which have determined the direction of the rockwall (SW-NE) as well as the Tajuña river valley (that gives name to the nearest village), located in its center.

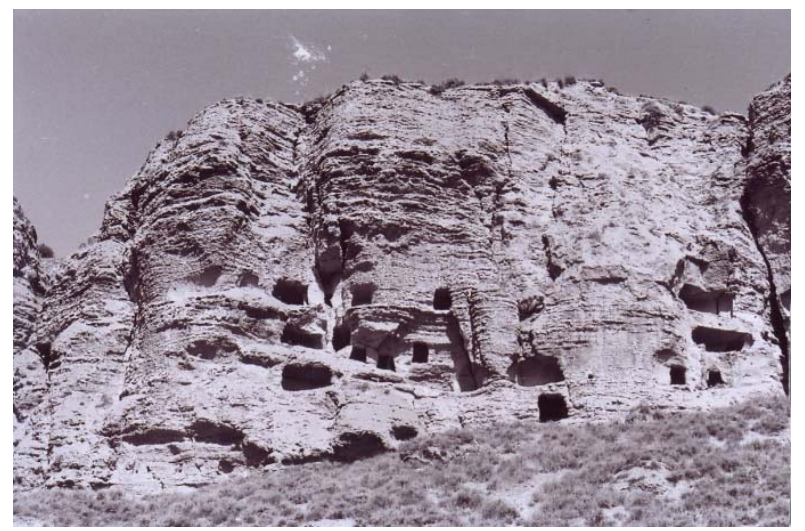

Fig. 1. View of the Risco de las Cuevas of Perales de Tajuña (Madrid) 


\section{Materials and methods}

In order to obtain the escarpment geometry, a series of photos were taken using a Canon 5D Mark II digital camera at focal lengths of $16 \mathrm{~mm}$ and $35 \mathrm{~mm}$. The series of photos were processed using digital photogrammetry software Photomodeler Scanner to obtain 3D point cloud of the studied slope. By further processing and meshing the 3D pointcloud it was possible to calculate the slope height, volumes of selected fallen blocks, and areas of shear surfaces of sliding blocks. The point cloud will be used as the benchmark for monitoring the erosion and material loss from the face of the rockwall in the future. To study the evolution of rockwall, old photographs have been used, which have been searched through the village and archaeological associations.

In order to analyze the effect of humidity and temperature on the rock, tree accelerated artificial ageing tests were reproduced in the laboratory: The freezing/thawing tests consisted of 24 hour cycles: 17 hours of total immersion in room temperature water $\left(20^{\circ} \pm 5^{\circ} \mathrm{C}\right)$, and 7 hours of freezing at $-16^{\circ} \mathrm{C}$. The wetting/drying test was performed in 24 hour cycles: 17 hours in room temperature water immersion followed by 6 hours in a laboratory oven at $50^{\circ} \mathrm{C}$ and one hour in a dryer. Another accelerated ageing test by wetting/drying (modified) was performed, consisted of cycles of 17 hours in a laboratory oven at $50^{\circ} \mathrm{C}$ and 1 hour in a dryer for cooling to room temperature, and complete immersion during 6 hours in room temperature water. Each accelerated ageing test was concluded at 105 cycles. The material decay evaluation has been carried out by means of the control of its weight loss in each one of the cycles.

Each one of these artificial ageing tests has been performed with 9 samples, divided in 3 groups (fig. 2), based on the amount of clay minerals (Illite, Smectite and Kaolinite). Type 1 gypsum with less of 5\% in clay content, type 2, gypsum with clay content between $5 \%$ and $15 \%$ and type 3 with a higher clay content, more than $15 \%$.

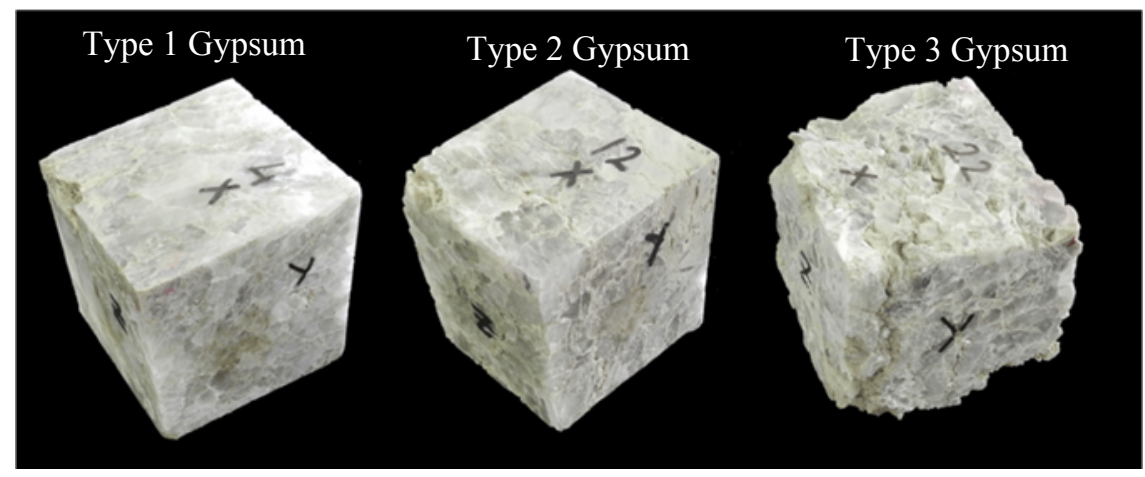

Fig 2. Different types of gypsum studied, divided by the amount of clay. 


\section{Results}

A high number of old photographs was collected, taken since 1890, which have been processing. From them, it is know that the last great rock fall happened at the beginning of the 20th century, a gypsum block of about $736 \mathrm{~m}^{3}$ and 1600 tons weigh. It fell with a shear surface of about $354 \mathrm{~m}^{2}$ area, measured by the photogrammetry analysis.

The gypsum durability has been evaluated measuring the weight loss of the specimens. The type 3 gypsum has experienced the most severe decay (fig. 3 ) in all the test. These samples have undergone disintegration in its entire perimeter and in cycle number 75 of freezing/thawing test, these specimens have lost almost $90 \%$ of its weight. For the modified wetting/drying test, $16.2 \%$ and for the standard wetting/drying test, $12.9 \%$.

This weight loss was continuous throughout the cycles and, possibly, greater number of cycles performed, the specimens would lead to the complete disintegration if increasing the number of cycles. Mass loss occurred primarily during the melting step, with the test pieces of gypsum immersed in water at $20^{\circ} \mathrm{C}$.

The decay of the type 1 and 2 gypsum has been very similar, with less decay of type 1 gypsum, which its weight loss is due to the dissolution by artificial accelerated ageing tests. The samples belonging to the gypsum without clay (type 1) experienced less weight loss: $14.2 \%$ for freezing/thawing, $4.9 \%$ for modified wetting/drying test and $5.2 \%$ for the standard wetting/drying test.

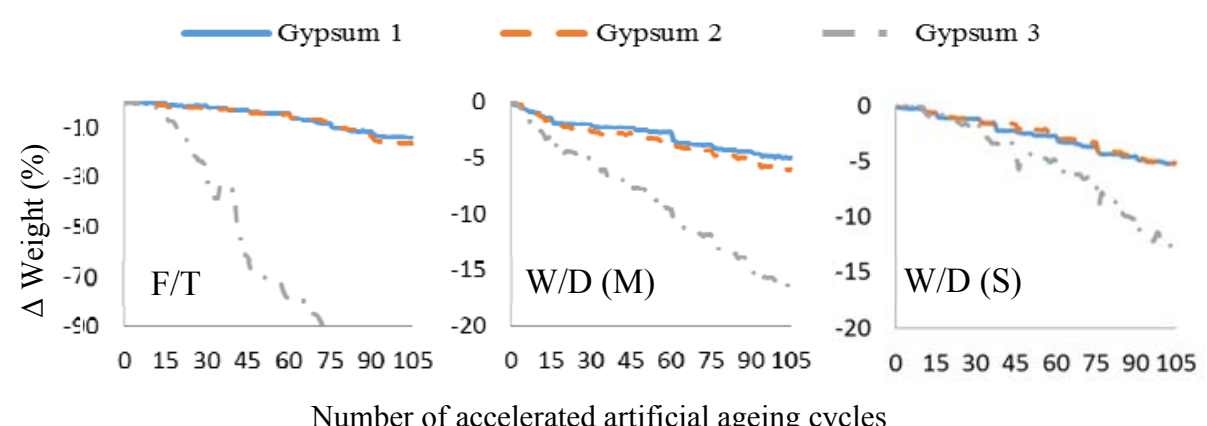

Fig. 3 Weight variation of three groups of gypsum in each testing artificial ageingaccelerated test. F/T (Freezing/thawing), W/D (M) (modified wetting/drying test), W/D (S) (standard Wetting/drying). 


\section{Conclusions}

The Risco de las Cuevas decay is favored by the mineral composition of the gypsum rocks, with different clay content of subhorizontal layers, the geomorphology (with an almost vertical slope) and by the climate, with a noticeable cyclical nature of temperature and humidity.

The artificial ageing tests allowed to determine how the clay mineral content is the key factor that controls the decay, being the most aggressive ageing test the freezing/thawing one, with a faster material loss of the samples with a higher content in these minerals. Although the deterioration process takes place in different ways, the water participates actively form in each one of them: ice water frost, dissolution, water retention with an increase of weight, and clays lixiviation. These factors generate specific damages and all of them contribute to the rock decay. It is important to minimize the water inflow.

The severity of wetting/drying cycles influences the gypsum durability. Modified wetting/drying test was more aggressive (a higher weight loss) than the standard wetting/drying test, which kept more uniform moisture conditions of gypsum samples (a shorter drying).

Another experience in terms of valuing cultural heritage that would contribute to its preservation is the so-called geomonumental routes (http://www.madrimasd.org/English/Science-Society/scientific-heritage/Geomonumental-Routes/default.asp), through which the geological features and the cultural value of the El Risco de las Cuevas are shown to the society. These activities have been carried out in the site during the last two years in the frame of the Science Week, with successful results.

\section{Acknowledgements}

This paper is part of the program Geomateriales (S2009 / MAT-1629), funded by the Community of Madrid. Thanks to the Petrophysics Laboratory of the Institute of Geosciences, (CSIC, UCM), belonging to the Laboratories Network on Heritage Science and Technology (RedLabPat), CEI-Moncloa (UCM- UPM, CSIC), and to the laboratories Network of the Community of Madrid (RedLab) where the laboratory testing was performed.Funding from the UCM research group "Applied Petrology for Heritage Conservation Research Group” is also acknowledged. 


\section{References}

[1] Reyes Téllez, F. (2009) El Risco de las Cuevas, en Perales de Tajuña. Anales de Arqueología Cordobesa 20:203-230

[2] Freire-Lista, D.M., Martínez-Garrido, M.I., Fort R. (2014) Monitoring techniques for microclimatic analysis in cultural and natural heritage for decay evaluation. Art'14, 11th international conference on Non-Destructive Investigations and Microanalysis for the Diagnostics and Conservation of Cultural and Environmental Heritage. Madrid 11th-14th june. In press.

[3] Hall, K., Thorn, C., Sumner, P. (2012) On the persistence of weathering. Gemorphology 1-10:149-150

[4] Spanish law 10/1998, July 9th, of historical heritage, Community of Madrid (Spain)

[5] Ponziani, D., Ferrero, E., Appolonia, L., Migliorini, S. (2012) Effects of temperature and humidity excursions and wind exposure on the arco of Augustus in Aosta. Journal of Cultural Heritage 13:462-468

[6] Ergüler, Z. A. (2009) Field-based experimental determination of the weathering rates of the Cappadocian tuffs. Engineering Geology 105:186-199

[7] Calvo, J. P., Ordóñez, S., García del Cura, M. A., Hoyos, M., Alonso-Zarza, A.M., Sanz, E., Rodríguez Aranda, J.P. (1989) Sedimentología de los complejos lacustres miocenos de la Cuenca de Madrid. Acta Geológica hispánica 24:281-298

[8] Garrote J, Garzón G, Tom R (2008) Multi-stream order analyses in basin asymmetry: A tool to discriminate the influence of neotectonics in fluvial landscape development (Madrid Basin, Central Spain). Geomorphology 102:130-144 